\title{
Octreotide and Bromocriptine Suppress Thyroid Hormone Levels and Thyroid Nodule in an Acromegalic Patient with Nontoxic Autonomous Goiter
}

\author{
NAOKI SAKANE, TOSHIHIDE YOSHIDA, AKIRA SHIMATSU*, \\ TUNEKAZU UMEKAWA, AND MOTOHARU KONDO \\ First Department of Internal Medicine, Kyoto Prefectural University of Medicine, Kyoto 602, and \\ *Department of Laboratory Medicine Kyoto University Graduate School of Medicine, Kyoto 606, Japan
}

\begin{abstract}
An acromegalic patient with nontoxic autonomous goiter was sequentially treated with octreotide and bromocriptine. Before therapy, serum GH, PRL and insulin-like growth factor-I (IGF-I) levels were increased. Free $T_{3}$ and free $T_{4}$ were within the normal range with suppressed TSH levels, whereas 123Iodine-uptake of thyroid was $5.6 \%$ after $24 \mathrm{~h}$. During treatment with octreotide and bromocriptine, serum GH, PRL, and IGF-I became normal and free $\mathrm{T}_{3}$ and free $\mathrm{T}_{4}$ were slightly but significantly decreased, but TSH levels remained very low. After thyroidectomy, thyroglobulin, free $\mathrm{T}_{3}$ and free $\mathrm{T}_{4}$ were further decreased, and the TSH levels were recovered to normal. These findings suggested that octreotide and bromocriptine inhibit the release of thyroid hormones from the autonomous thyroid gland directly or indirectly through the decline in IGF-I.
\end{abstract}

Key words: Acromegaly, Autonomous goiter, Octreotide, Bromocriptine, Thyroid function

(Endocrine Journal 44: 305-310, 1997)

IN acromegalic patients, several abnormalities related to the thyroid and the pituitary-thyroid axis, such as goiter formation, changes in serum thyroid hormone levels and impaired TSH response to TRH, have been described [1-6]. In most studies, serum $\mathrm{T}_{4}, \mathrm{~T}_{3}$ and basal TSH levels are found to be normal. Both octreotide and bromocriptine are used to treat acromegaly, and acute administration of these drugs is reported to suppress TSH secretion $[7,8]$, but chronic treatment with octreotide or bromocriptine did not alter thyroid function in most patients with acromegaly [9-11]. In this report, we describe an acromegalic case with nontoxic autonomous goiter which shows that

Received: July 9, 1996

Accepted: November 28, 1996

Correspondence to: Dr. Toshihide YOSHIDA, First Department of Internal Medicine, Kyoto Prefectural University of Medicine, 465 Kajiicho, HirokojiKawaramachi, Kamikyo-ku, Kyoto 602, Japan octreotide and bromocriptine inhibit both $\mathrm{GH}$ secretion and thyroid function.

\section{Case Report}

A 50-year-old housewife was referred to us in March, 1991 because of acromegalic features and enlarged thyroid gland. She had had amenorrhea since the age of 36 and general fatigue for five years. On admission she had the physical stigmata of acromegaly with galactorrea. Opthalmological examination was unremarkable. The right lobe of the thyroid gland was enlarged $(7.5 \mathrm{~cm} \times 4.5 \mathrm{~cm}$ in size). Magnetic resonance imaging study suggested the existence of a microadenoma in the pituitary. Table 1 shows the basal levels of hormones on admission. Serum GH, PRL and IGF-I were increased. Free $T_{3}$ and free $T_{4}$ were within the normal range with undetectable TSH. Antimicrosomal antibodies and antithyroglobulin 
Table 1. Endocrinological data on admission

\begin{tabular}{lcc}
\hline \multicolumn{2}{l}{ Serum hormone } & Normal range/values \\
\hline $\mathrm{GH}$ & $21 \mu \mathrm{g} / l$ & $<5.0$ \\
$\mathrm{PRL}$ & $56.2 \mu \mathrm{g} / l$ & $1.5-9.7$ \\
$\mathrm{ACTH}$ & $11 \mathrm{pmol} / l$ & $<17$ \\
Cortisol & $320 \mathrm{nmol} / l$ & $150-590$ \\
$\mathrm{LH}$ & $1.6 \mathrm{IU} / l$ & $1.8-5.2$ \\
$\mathrm{FSH}$ & $7.1 \mathrm{IU} / l$ & $2.9-8.2$ \\
$\mathrm{TSH}$ & $<0.02 \mathrm{mU} / l$ & $0.34-3.5$ \\
Free $\mathrm{T}_{3}$ & $6.5 \mathrm{pmol} / l$ & $4.5-8.9$ \\
Free & $23 \mathrm{pmol} / l$ & $11-28$ \\
IGF-I & $872 \mu \mathrm{g} / l$ & $79-383$ \\
PTH & $510 \mathrm{ng} / l$ & $230-560$ \\
\hline
\end{tabular}

IGF-I, insulin-like growth factor-I; PTH, parathyroid hormone.

antibodies were absent, as was the TSH receptor antibody. The hypophysio-adrenal and gonadal axis were normal. Oral glucose loading showed signs of impaired glucose tolerance. The administration of TRH evoked marked GH responses. TSH responses to TRH were completely suppressed. The oral administration of L-dopa or bromocriptine decreased GH. 123Iodine and 201thallium scintigraphies of the thyroid showed the heterogeneous distribution of radioactivities with multiple cold and warm areas (Fig. 1). 123Iodine uptake of the thyroid was $5.6 \%$ after $24 \mathrm{~h}$. The computed tomography of the thyroid showed a large nodule in the right lobe (Fig. 2A). The patient was diagnosed as having active acromegaly with adenomatous goiter. Since transsphenoidal adenomectomy was not acceptable, she received trials of $150 \mu \mathrm{g}$ daily subcutaneous injections of

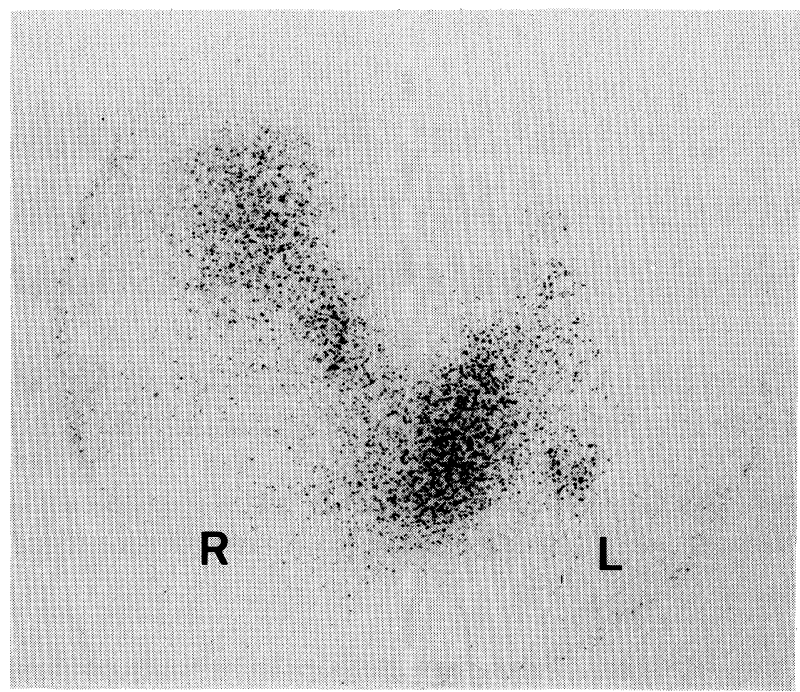

Fig. 1. 123I-scintigraphy of the thyroid gland showing several cold and warm areas with normal uptake (5.6\% after $24 \mathrm{~h}$ )

octreotide for 2 weeks, and serum GH, PRL and IGF-I were decreased (Table 2). Free $\mathrm{T}_{3}$ and free $\mathrm{T}_{4}$ were slightly but significantly decreased $(P<0.05)$, and TSH remained very low. She subsequently received bromocriptine daily at a dose of $5 \mathrm{mg}$ in two divided doses. PRL levels were decreased markedly, and GH, IGF-I, free $T_{3}$, and free $\mathrm{T}_{4}$ remained stable. The size of the thyroid nodule was reduced from $7.5 \times 4.5 \mathrm{~cm}$ to $5.6 \times 3.5$ $\mathrm{cm}$ after octreotide therapy for 2 weeks and bromocriptine for 4 weeks (Fig. 2B). Magnetic resonance imaging showed a slight reduction in

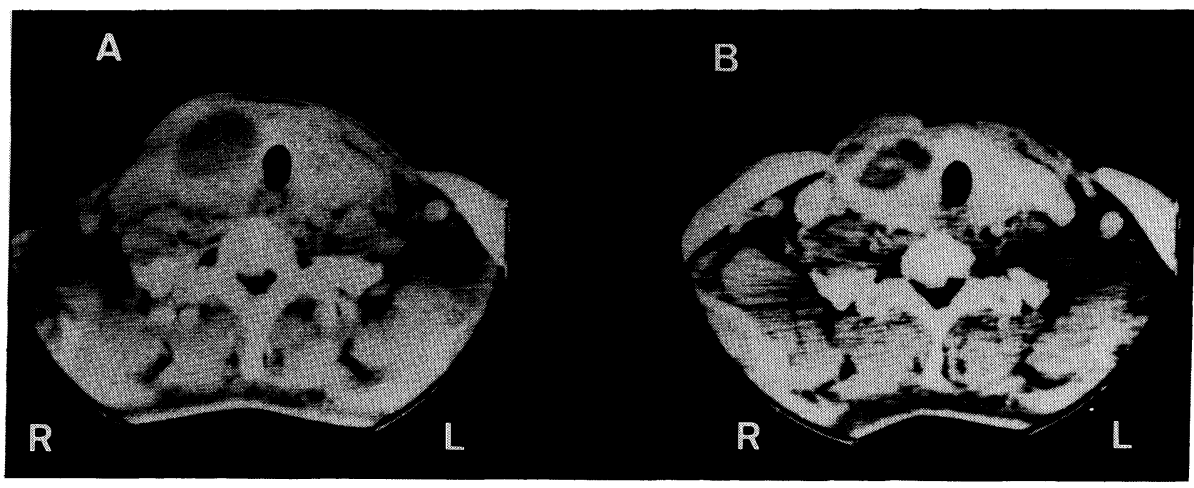

Fig. 2. A: Computed tomography of the enhanced thyroid, showing a large thyroid tumor before treatment $(7.5 \times 4.5 \mathrm{~cm}$ in diameter), B: Computed tomography of the thyroid after octreotide therapy for 2 weeks and bromocriptine therapy for 4 weeks (nodule decreased to $5.6 \times 3.5 \mathrm{~cm}$ in diameter). 
Table 2. Clinical course of the patient

\begin{tabular}{|c|c|c|c|c|c|c|c|}
\hline & $\begin{array}{c}\mathrm{GH} \\
(\mu \mathrm{g} / l)\end{array}$ & $\begin{array}{c}\text { PRL } \\
(\mu \mathrm{g} / l)\end{array}$ & $\begin{array}{l}\text { IGF-I } \\
(\mu \mathrm{g} / l)\end{array}$ & $\begin{array}{c}\text { Free } \mathrm{T}_{3} \\
(\mathrm{pmol} / l)\end{array}$ & $\begin{array}{c}\text { Free } \mathrm{T}_{4} \\
(\mathrm{pmol} / \mathrm{l})\end{array}$ & $\begin{array}{c}\mathrm{TSH} \\
(\mathrm{mU} / l)\end{array}$ & $\begin{array}{l}\text { Thyroglobulin } \\
(\mu \mathrm{g} / l)\end{array}$ \\
\hline March 11 April 26 & $\begin{array}{c}18 \pm 2.2^{\mathrm{a})} \\
(72)^{\mathrm{b})}\end{array}$ & $\begin{array}{c}51.5 \pm 4.9 \\
(68.5)\end{array}$ & 872 & $6.5 \pm 0.3$ & $22 \pm 1$ & $\begin{array}{l}0.02 \pm 0.01 \\
\quad(0.05)\end{array}$ & 783 \\
\hline April 27 May $\left.10^{c}\right)$ & $2 \pm 0$ & $21.5 \pm 1.4$ & 282 & $4.5 \pm 0.3^{*}$ & $18 \pm 2^{*}$ & $\begin{array}{l}0.04 \pm 0.01 \\
\quad(0.08)\end{array}$ & 478 \\
\hline May 11 June $4^{\text {d) }}$ & $4.4 \pm 1.6$ & $0.9 \pm 0.1$ & 166 & $4.6 \pm 0.5^{*}$ & $17 \pm 1^{*}$ & $0.04 \pm 0.01$ & 430 \\
\hline June 5 June $24^{\mathrm{e})}$ & $9.0 \pm 0.4$ & $\begin{array}{c}2.1 \pm 1.1 \\
(13.2)\end{array}$ & 344 & $1.8 \pm 0.2$ & $8 \pm 2$ & $\begin{array}{c}12.1 \pm 11.7 \\
\quad(32.8)\end{array}$ & 47 \\
\hline June $25 \sim$ August $27^{f}$ ) & $5.6 \pm 1.7$ & $2.2 \pm 0.9$ & 306 & $4.9 \pm 0.5$ & $19 \pm 4$ & $6.6 \pm 3.9$ & 45 \\
\hline
\end{tabular}

a) mean $\pm \mathrm{SD}$ ( $\mathrm{n}=3 \sim 5$ determination). ${ }^{\text {b) }}$ peak GH, PRL or TSH level during TRH test. ${ }^{\mathrm{c}}$ under octreotide treatment. ${ }^{d)}$ under bromocriptine treatment; before total thyroidectomy. ${ }^{\text {e) }}$ under bromocriptine treatment; after surgery and before thyroxine supplement. ${ }^{f}$ under bromocriptine and thyroxine therapy. ${ }^{*} P<0.05$ Mann-Whitney's U test was performed vs. March 11 April 26.

pituitary tumor size after octreotide and bromocriptine treatments, but she underwent total thyroidectomy on June 5th, 1991 because of compressive symptoms due to the large adenomatous goiter. Histological examination of the thyroid gland showed adenomatous goiter with a very small focus of papillary carcinoma. After thyroidectomy, free $T_{3}$ and free $T_{4}$ levels were further decreased, and TSH levels were reciprocally increased and responded to TRH. Since June 25th, 1991, she has received supplementation of thyroxine at a dose of $100 \mu \mathrm{g}$ daily, and her TSH levels returned normal. Her hyperprolactinemia was considered to be due to the tumoral production, although no histological evidence was provided.

\section{Methods}

The concentrations of $\mathrm{GH}$ and $\mathrm{TSH}$ were measured with IRMA kits (GH kit and TSH kit by Daiichi RI, Tokyo, Japan). The concentrations of free $T_{3}$, free $T_{4}, P R L$ and IGF-I were measured with commercial TIA kits [Daiichi RI (Tokyo) for free $\mathrm{T}_{3}$ and free $\mathrm{T}_{4}$; Dainabot (Tokyo) for PRL; CibaCorning (Tokyo) for IGF-I]. The intra- and inter-assay coefficients of variation of the IRMAs and RIAs were all within $10 \%$. TSH receptor antibody was measured with a kit from Johnson \& Johnson Clinical Diagnostics Ltd., Amersham, England.

\section{Discussion}

The present case showed thyroid enlargement, increased thyroglobulin and normal free $T_{3}$ and free $\mathrm{T}_{4}$, although TSH was completely suppressed and 123Iodine-uptake of the thyroid was normal. In most acromegalic patients, TSH response to TRH is impaired due to the inhibition by excessive hypothalamic somatostatin, but complete suppression of TSH is rather rare in cases with preserved anterior pituitary functions. Wüster $e t$ al. [5] showed that 10 out of 80 patients with acromegaly had thyroid autonomies. Gemsenjäger et al. [12] reported that some patients with nontoxic multinodular goiter showed no TSH response to TRH, suggested a state of preclinical hyperthyroidism. The present patient clearly had a nontoxic autonomous goiter with suppressed TSH in spite of normal free $T_{3}$ and free $T_{4}$ levels.

During octreotide and bromocriptine treatment, both free $T_{4}$ and free $T_{3}$ slightly but significantly decreased in the present case of autonomous goiter. This is rather in contrast to the previous observations in most acromegalic patients [9, 10, $12,13]$. After two month's bromocriptine treatment (7.5-50 mg/day) of fifteen acromegalic patients, $T_{3}$ and $\mathrm{T}_{4}$ levels were not affected by treatment $\left(\mathrm{T}_{4}\right.$ : from $6.65 \pm 0.52 \mu \mathrm{g} / \mathrm{d} l$ to $7.33 \pm 0.79 \mu \mathrm{g} / \mathrm{d} l ; \mathrm{T}_{3}$ : from $1.25 \pm 0.06 \mathrm{ng} / \mathrm{ml}$ to $1.44 \pm 0.10 \mathrm{ng} / \mathrm{ml}$ ) [9] After one or two month's octreotide treatment, $\mathrm{T}_{3}$ and $\mathrm{T}_{4}$ levels also were not affected by treatment 


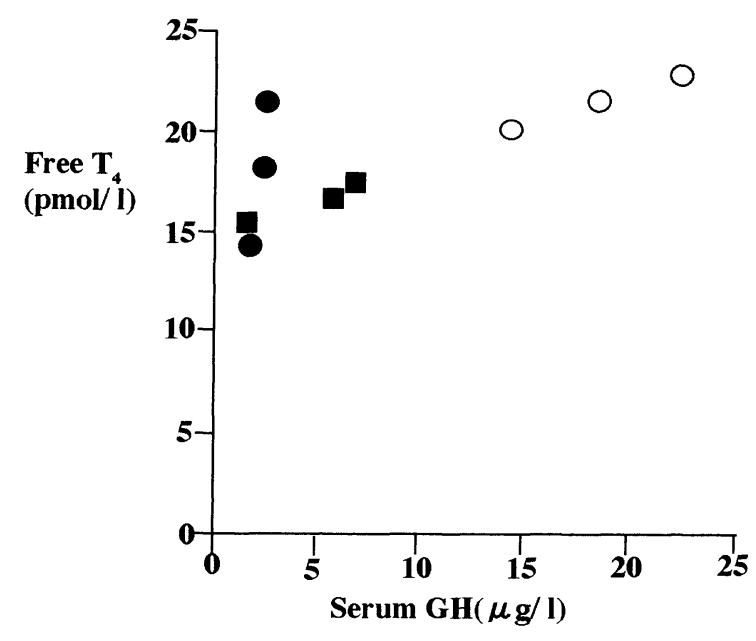

Fig. 3. Serum $\mathrm{GH}$ and free $\mathrm{T}_{4}$ levels during clinical course before thyroidectomy. $\bigcirc$, control period; - under octreotide therapy; $\boldsymbol{\square}$, under bromocriptine therapy before thyroidectomy. The positive correlation was observed $(n=9$, $\mathrm{r}=0.737, P<0.02$ ).

( $\mathrm{T}_{4}$ : from $8.1 \pm 0.6 \mu \mathrm{g} / \mathrm{d} l$ to $8.0 \pm 0.5 \mu \mathrm{g} / \mathrm{d} l$ ) [10]. The reason for the discrepancy remains to be determined, but previous studies did not discriminate between acromegalic patients who had thyroid autonomy and those who did not.

Administration of octreotide or bromocriptine inhibits TSH secretion $[7,8,13]$, but altered thyroid function in the present case may not be due to TSH secretion, since TSH levels were always suppressed. Roelfsema and Frölich [14] suggested that octreotide inhibits the peripheral conversion of $T_{4}$ to $T_{3}$. This may be secondary to the decrease in $\mathrm{GH}$ levels caused by octreotide, since $\mathrm{GH}$ stimulates peripheral deiodination of $\mathrm{T}_{4}$ [15-17]. We observed a positive correlation between GH levels and free $\mathrm{T}_{4}$ levels in the present case (Fig. 3). Yoshinari et al. [6] reported that IGF-I values were correlated with free $T_{4}$ values in patients with normal and suppressed TSH, suggesting that IGFI was stimulating thyroid hormone production, but no direct evidence was reported to prove that $\mathrm{GH}$ and IGF-I exert stimulatory effects on thyroidal iodine metabolism. On the contrary, the radioiodine uptake was inhibited with IGF-I [18]. $\mathrm{T}_{4}$ levels remained constant in acromegalic patients before and after successful transsphenoidal surgery and only $T_{3}$ transiently decreased in immediate postoperative period [4].

Another explanation is that somatostatin may directly inhibit $T_{4}$ and $T_{3}$ release from the autonomous thyroid. Somatostatin receptors were detected in human thyroid cell lines and tissues [19]. Somatostatin is reported to suppress the release of $T_{4}$ and $T_{3}$ from human thyroid in response to exogenous TSH $[20,21]$ and turnover of TSH-stimulated radioactive iodine accumulation in thyroid glands [22]. Furthermore, somatostatin infusion decreased serum $\mathrm{T}_{4}$ and $\mathrm{T}_{3}$ levels [23-25]. The reduction in thyroid hormone values was maintained during bromocriptine therapy after stopping octreotide treatment. It is difficult to explain why bromocriptine was equally effective in reducing thyroid hormone secretion, since dopamine itself was reported to stimulate thyroidal iodine metabolism [26]. Drugs or contrast media containing iodine might contribute to the reduction in hormone secretion, but the preserved iodine uptake of the thyroid may clearly exclude these possibilities.

The size of the thyroid nodule and serum thyroglobulin levels had decreased 6 weeks after octreotide and bromocriptine. The decrease in the size of the thyroid nodule may be due to the decrease in IGF-I during therapy, since IGF-I has been considered as a growth factor in thyroid tissues $[27,28]$. Our findings are in good agreement with the previous clinical observations by Miyakawa et al. [29]. It is also possible that somatostatin may directly inhibit the growth of the human thyroid gland $[19,30,31]$.

In conclusion, octreotide and bromocriptine may directly or indirectly inhibit the release of thyroid hormones from the autonomous thyroid gland associated with acromegaly.

\section{References}

1. Mukhtar E, Alexander L, Wilkinson R, Appleton D, Hall R (1971) Thyroid function in acromegaly. Lancet 2: 279-283.

2. Lamberg BA, Pelkonen R, Aro A, Grahne B (1976)
Thyroid function in acromegaly before and after transsphenoidal hypophysectomy followed by cryoapplication. Acta Endocrinology (Copenh) 82: 254 266. 
3. Nabarro JDN (1987) Acromegaly. Clin Endocrinol 26: 481-512.

4. Geelhoed-Duijvestijn PHLM, Bussemarker JK, Roelfsema F (1989) Changes in basal and stimulated TSH and other parameters of thyroid function in acromegaly after transsphenoidal surgery. Acta Endocrinology (Copenh) 121: 207-215.

5. Wüster C, Steger G, Schmelzle A, Gottswinter J, Minne HW, Ziegler R (1991) Increased incidence of euthyroid and hyperthyroid goiter independently of thyrotropin in patients with acromegaly. Horm Metab Res 23: 131-134.

6. Yoshinari M, Tokuyama T, Kuroda T, Sato $K$, Okazawa K, Mizokami T, Okamura K, Fujishima M (1992) Preserved thyroidal secretion of thyroxine in acromegalic patients with suppressed hypophyseal secretion of thyrotropin. Clin Endocrinol 36: 355-360.

7. Yap PL, Davidson NM, Lidgard GP, Fyffe JA (1978) Bromocriptine suppression of the thyrotropin response to thyrotropin releasing hormone. Clin Endocrinol 9: 179-183.

8. Davies RR, Miller M, Turner SJ, Goodship THJ, Cook DB, Watson M, Mcgill A, Orskov H, Alberti KGMM, Johnston DG (1986) Effects of somatostatin analogue SMS 201-995 in nomal man. Clin Endocrinol 24: 665-674.

9. Kobberling J, Darragh A, Del Pozo E (1979) Chronic dopamine receptor stimulation using bromocriptine: Failure to modify thyroid function. Clin Endocrinol 11: 367-370.

10. Barkan AL, Kelch RP, Hopwood NJ, Beitings IZ (1988) Treatment of acromegaly with the long acting somatostatin analogue SMS 201-995. J Clin Endocrinol Metab 66: 16-23.

11. Ho KY, Weissberger AJ, Marbach P, Lazarus L (1990) Therapeutic efficacy of the somatostatin analog SMS 201-995 (octretotide) in acromegaly. Ann Int Med 112: 173-181.

12. Gemsenjäger E, Staub JJ, Girard J, Heitz PH (1976) Preclinical hyperthyroidism in multinodular goiter. J Clin Endocrinol Metab 43: 810-816.

13. Christensen SE, Weeke J, Kaal A, Harris AG, Ørskov $H$ (1992) SMS 201-995 and thyroid function in acromegaly: Acute, intermediate and long term effects. Horm Metab Res 24: 237-239.

14. Roelfsema F, Frölich M (1991) Pulsatile thyrotropin release and thyroid function in acromegalics before and during subcutaneous octreotide infusion. J Clin Endocrinol Metab 72: 77-82.

15. Inada M, Sterling K (1967) Thyroxine turnover and transport in active acromegaly. J Clin Endocrinol Metab 27: 1019-1027.

16. Sato T, Suzuki $Y$, Taketani $T$, Ishiguro $K$, Masuyama T, Takata I, Sano M, Kawashima H, Koizumi S, Nakajima H (1977) Enhanced peripheral conversion of thyroxine to triiodothyronine during $\mathrm{hGH}$ therapy in GH deficienct children. J Clin Endocrinol Metab 45: 324-329.

17. Grunfeld C, Sherman BM, Cavalier RR (1988) The acute effects of human growth hormone administration on thyroid function in normal men. J Clin Endocrinol Metab 67: 1111-1114.

18. Brenner-Gait L, Berg KA, Gershengorn MC (1989) Insulin-like growth factor-I potentiates thyrotropin stimulation of adenyl cyclase in FRTL-5 cells. Endocrinology 125: 1315-1320.

19. Ain KB, Tayler KD (1994) Somatostatin analogs affect proliferation of human thyroid carcinoma cell lines in vitro. J Clin Endocrinol Metab 78: 1097-1102.

20. Loos U, Escobar-Jimenez F, Raptis S, Birk J, Rothenbuchner G, Pfeiffer EF (1977) Inhibition of TSH-induced release of tri-iodothyronine $\left(\mathrm{T}_{3}\right)$ and thyroxine $\left(\mathrm{T}_{4}\right)$ by somatostatin in man. Acta Endocrinol (Copenh) 208 (Suppl): 47-48.

21. Ahren $B$, Ericsson $M$, Hender $P$, Ingemansson $S$, Westgren U (1978) Somatostatin inhibits thyroid hormone secretion induced by exogenous TSH in man. J Clin Endocrinol Metab 47: 1156-1159.

22. Loos U, Raptis S, Birk J, Escobar-Jimenez F, Meyer G, Rothenbuchner G, Pfeiffer EF (1978) Inhibition of $\mathrm{TSH}$-stimulated radioiodine turnover and release of $\mathrm{T}_{4}$ and $\mathrm{T}_{3}$ in vivo by somatostatin. Metabolism 27 (Suppl 1): 1269-1273.

23. Lins PE, Efend S, Hall K (1979) Effect of 24-h somatostatin infusion on glucose homeostasis and on the levels of somatomedin A and pancreatic and thyroid hormones in man. Acta Medica Scandinavica 206: 441-445.

24. Weeke J, Christensen SE, Hansen AP, Laurberg P, Lund-Beak K (1980) Somatostatin and the $24 \mathrm{~h}$ levels of serum $\mathrm{TSH}, \mathrm{T}_{3}, \mathrm{~T}_{4}$, and reverse $\mathrm{T}_{3}$ in normals, diabetics and patients treated for myxoedema. Acta Endocrinol (Copenh) 94: 30-37.

25. Samuels MH, Henry P, Ridgway EC (1992) Effects of dopamine and somatostatin on pulsatile pituitary glycoprotein secretion. J Clin Endocrinol Metab 74: 217-222.

26. Melander A (1969) Amines and mouse thyroid activity: A thyroid-stimulating effect of 5hydroxytryptamine and dopamin. Acta Endocrinol (Copenh) 62: 565-576.

27. Tode B, Serio M, Rotella CM, Galli G, Franceschelli F, Tanini A, Toccafondi R (1989) Insulin-like growth factor-I: Autocrine secretion by human thyroid follicular cells in primary culture. J Clin Endocrinol Metab 69: 639-647.

28. Williams DW, Williams ED, Wyrfrd-Thomes D (1989) Evidence for autocrine production of IGF-I in human thyroid adenomas. Mol Cell Endocrinol 61: 139-143.

29. Miyakawa M, Saji M, Tsushima T, Wakai K, Shizume K (1988) Thyroid volume and serum thyroglobulin levels in patients with acromegaly: 
Correlation with plasma insulin-like growth factor I levels. J Clin Endocrinol Metab 67: 973-978.

30. Tsuzaki S, Moses AC (1991) Somatostatin inhibits deoxyribonucleic acid synthesis induced by both thyrotropin and insulin-like growth factor-I in FRTL5 cells. Endocrinology 126: 3131-3138.
31. Degli Uberti EC, Hanau S, Rossi R, del Senno L (1991) Somatostatin reduces ${ }^{3} \mathrm{H}$-thymidine incorporation and c-myc, but not thyroglobulin ribonucleic acid levels in human thyroid follicular cells in vitro. J Clin Endocrinol Metab 72: 1364-1371. 